\title{
Global Financial Crisis And Its Impact On Textile Industry In Pakistan
}

Faiz. M. Shaikh, SZABAC-Dokri, Pakistan

Nazir Ahmed Gopang, University of Sindh-Jamshoro, India

Kamran Shafiq, COMSATS-Abbott bad

\begin{abstract}
This research investigates the impact of Global Financial Crisis on textile industry clusters in Pakistan. A cross sectional data were collected from 25 textile industries by using simple random technique and data were analysis by using E-Views software. Structural questionnaire was the basic tool for measures the performance of textile industry in financial recession in Pakistan. It was revealed that the industry is in urgent need of financial and technological investments. It was revealed that Global financial crisis has negative impact on the export of textile industry in Pakistan. The export of textile related products has decreased by 20 percent due to decrease in textile demand. It was further revealed that textile industry facing problems such as electricity and high taxes.
\end{abstract}

Keywords: textile; clusters; empirical analysis; Pakistan

\section{INTRODUCTION}

lobal Financial Crisis hit many economies of the world including Pakistan. It now appears that the financial crises that have gripped America and Europe and also affect the real economies of these countries like Pakistan. Most experts now believe that America and Europe at this time stand at the threshold of deep recessions. The first signs of these have already begun to appear. In September, Americans lost 160,000 jobs; it is expected that by the end of the year there will be a reduction of one million jobs in the United States. Job losses result in declines in spending. Trade, in other words, will transmit to many developing countries the shocks of the current financial crisis in the western world. Global financial crisis has negative impact on the rural poverty in Sindh (F.M.Shaikh et, al 2009)

\section{COUNTRY ANALYSIS}

\section{Background}

The population of Pakistan is approximately 181 million people and it is the sixth most-populous country. Geographically, it is situated in south Asia with its borders with India in the East and Afghanistan in the West. About $20 \%$ of the population lives below the international poverty line of US\$1.25 a day (Economic Survey of Pakistan-2008-09).

\section{Pakistan Export Situation}

The main export items of Pakistan are rice, furniture, cotton fiber, textiles, leather etc (Textile Vision 2005, 2000). Exports were targeted at $\$ 19.0$ billion or $6.9 \%$ lower than last year. Exports started to face global financial crisis since November 2008 and the contraction of world over demand has exacerbated export contraction. The manufacturing sector contributes to around half of the total exports and textile sector contributes around $46 \%$ of the manufacturing sector's contribution. Exports shrank from $\$ 16.4$ billion to $\$ 16.0$ billion or a $2.6 \%$ decline. In terms of export clusters, Pakistan's economy is mostly concentrated in textile \& apparel, leather goods, agricultural products, construction material, logistics, transportation, fruits, row cotton, fish, vegetables and sports good. Out of 
which Textile \& apparel are the biggest and the fastest growing clusters. The challenge for Pakistan is thus to develop other emerging clusters to expand its portfolio.

\section{Business Environment Of Pakistan}

Pakistan's national business environment is characterized by abundance of semi-skilled and low wage labor, moderate natural resources, poor infrastructure, high rates of corruption, poor governance, moderate level of university-industry collaboration and low scientific research on the factor side. American Business Council of Pakistan (ABC), a formal association of American Multinationals operating in Pakistan conducts informal business survey annually to assess how their members view investment climate in Pakistan. The survey conducted in July August, 2002, shows that Pakistan's economy is picking up and the investment environment is improving (sheikh, 2005).

\section{Key Results Of The Survey}

- $\quad 85 \%$ of respondents indicated improvement in Pakistan's overall economic prospects while $73 \%$ indicated improvement in Domestic Economy.

- $\quad 83 \%$ reported increase in their revenues in Rupees while $78 \%$ in US \$ terms.

- $\quad 79 \%$ observed that the policies were more consistent than before while $68 \%$ felt that the Government was positively impacting business.

- $\quad 75 \%$ indicated increase in their pre-tax profits.

- $\quad 63 \%$ indicated improvement in implementation of policies by the Government.

- $\quad 51 \%$ of the respondents reported that they were planning to expand investment in Pakistan.

\section{Data Collection Methodology}

A cross sectional Data were collected from 25 textile industries by using simple random technique and data were analysis by using E-Views software. A structural questionnaire was developed as basic tool of measurement of textile industry in Pakistan.

\section{CLUSTER ANALYSIS}

\section{Importance Of The Textile Cluster}

The Textiles and Apparels is the backbone of Pakistan's economy. In 2005, textile's contribution to overall GDP was $10 \%$ while its share in the exports was at a high of $60 \%$. Moreover, it is the biggest source of employment in the country providing employment to more than 1.3 million people. About $38 \%$ of the manufacturing sector employment is in textile sector.

Table 1

\begin{tabular}{|c|c|c|c|c|}
\hline Year & GDP-real growth rate & Rank & Percent Change & Date of Information \\
\hline 2003 & $4.50 \%$ & 48 & & FY01/02 est. \\
\hline 2004 & $5.50 \%$ & 45 & $22.22 \%$ & 2003 est. \\
\hline 2005 & $6.10 \%$ & 47 & $10.91 \%$ & 2004 est. \\
\hline 2006 & $6.60 \%$ & 48 & $8.20 \%$ & 2005 est. \\
\hline 2007 & $6.60 \%$ & 59 & $0.00 \%$ & 2006 est. \\
\hline 2008 & $5.30 \%$ & 104 & $-19.70 \%$ & 2007 est. \\
\hline
\end{tabular}

Source: World Development Indicators, 2008-09 
Table 2.2 Pakistan share of major commodities in worlds contribution

\begin{tabular}{|c|c|c|c|c|c|c|c|c|}
\hline & 1977 & 1982 & 1987 & 1989 & 1991 & 1992 & 1993 & 1994 \\
\hline \multicolumn{9}{|l|}{ Total Export } \\
\hline World Total & 1041000 & 1882355 & 2527885 & 3080000 & 3506000 & 3642000 & 3257589 & 3617591 \\
\hline Pakistan & 1283 & 2348 & 4105 & 4698 & 6464 & 7264 & 6842 & 7328 \\
\hline Share & 0.12 & 0.12 & 0.16 & 0.15 & 0.18 & 0.20 & 0.21 & 0.20 \\
\hline \multicolumn{9}{|c|}{ Textile and Clothing } \\
\hline World Total & 69071 & 75217 & 166200 & 193900 & 196834 & 222708 & 217926 & 238433 \\
\hline Pakistan & 1521 & 1071 & 2447 & 2734 & 4423 & 5041 & 5091 & 5593 \\
\hline Share & 2.20 & 1.42 & 1.47 & 1.41 & 2.25 & 2.26 & 2.34 & 2.35 \\
\hline \multicolumn{9}{|c|}{ Leather and Leather Goods } \\
\hline World Total & 2339 & 4115 & 7949 & 8706 & 10660 & 11751 & 12697 & 14645 \\
\hline Pakistan & 64 & 104 & 270 & 265 & 271 & 254 & 240 & 269 \\
\hline Share & 2.74 & 2.53 & 3.40 & 3.04 & 2.54 & 2.16 & 1.89 & 1.84 \\
\hline \multicolumn{9}{|c|}{ Fish and Fish Products } \\
\hline World Total & 23862 & 12225 & 22126 & 24588 & 31982 & 33038 & 33384 & 36531 \\
\hline Pakistan & 36 & 79 & 121 & 92 & 110 & 137 & 202 & 143 \\
\hline Share & 0.15 & 0.65 & 0.55 & 0.37 & 0.34 & 0.41 & 0.61 & 0.39 \\
\hline \multicolumn{9}{|c|}{ Carpets, Carpeting and Rugs } \\
\hline World Total & 531 & 857 & 1089 & 1199 & 1123 & 1346 & 1440 & 1213 \\
\hline Pakistan & 103 & 136 & 225 & 224 & 217 & 204 & 158 & 187 \\
\hline Share & 19.40 & 15.90 & 20.66 & 18.70 & 19.32 & 15.16 & 10.97 & 15.42 \\
\hline
\end{tabular}

Source: General of economic corporation among Islamic countries

\begin{tabular}{|l|c|c|c|c|c|c|}
\hline \multirow{2}{*}{ Series } & \multicolumn{2}{|c|}{ * November, 2006 } & \multirow{2}{*}{ * October, 2006 } & \multicolumn{2}{c|}{$\begin{array}{c}\text { \% Change in } \\
\text { November, 2006 over } \\
\text { October, 2006 }\end{array}$} \\
\cline { 2 - 7 } & Rs. & $\$$ & Rs. & $\$$ & Rs. & $\$$ \\
\hline Exports & 83,805 & $1,380,001$ & 77,688 & $1,282,058$ & 7.87 & 7.64 \\
\hline Imports & 168,433 & $2,773,554$ & 129,170 & $2,131,662$ & 30.40 & 30.11 \\
\hline Balance of Trade & $-84,628$ & $-1,393,553$ & $-51,482$ & $-849,604$ & 64.38 & 64.02 \\
\hline
\end{tabular}

\begin{tabular}{|l|c|c|c|c|c|c|}
\hline \multirow{2}{*}{ Series } & \multicolumn{3}{|c|}{ November, 2006 } & \multicolumn{2}{c|}{ November, 2005 } & \multicolumn{2}{c|}{$\begin{array}{c}\text { \% Change in } \\
\text { November, 2006 over } \\
\text { November, 2005 }\end{array}$} \\
\cline { 2 - 7 } & Rs. & $\$$ & Rs. & $\$$ & Rs. & $\$$ \\
\hline Exports & 83,805 & $1,380,001$ & 66,546 & $1,113,472$ & 25.94 & 23.94 \\
\hline Imports & 168,433 & $2,773,554$ & 137,400 & $2,299,021$ & 22.59 & 20.64 \\
\hline Balance of Trade & $-84,628$ & $-1,393,553$ & $-70,854$ & $-1,185,549$ & 19.44 & 17.54 \\
\hline
\end{tabular}

\begin{tabular}{|l|c|c|c|c|c|c|}
\hline \multirow{2}{*}{ Series } & \multicolumn{2}{|c|}{$\begin{array}{c}\text { * July - November } \\
2006\end{array}$} & \multicolumn{2}{c|}{$\begin{array}{c}\text { \%uly - November } \\
\text { 2005 }\end{array}$} & \multicolumn{2}{c|}{$\begin{array}{c}\text { July - November, 2006 over } \\
\text { July- November, 2005 }\end{array}$} \\
\cline { 2 - 7 } & Rs. & $\$$ & Rs. & $\$$ & Rs. & $\$$ \\
\hline Exports & 418,937 & $6,927,683$ & 393,548 & $6,591,866$ & 6.45 & 5.09 \\
\hline Imports & 745,989 & $12,333,301$ & 667,277 & $11,176,213$ & 11.80 & 10.35 \\
\hline Balance of Trade & $-327,052$ & $-5,405,618$ & $-273,729$ & $-4,584,347$ & 19.48 & 17.91 \\
\hline
\end{tabular}

Source: Govt. of Pakistan statistic division federal bureau of statistic Provisional figures are based on figure provided by the member (FB\&S) CBR, Islamabad. 
Note: Rupee value is converted into US\$ on monthly average exchange rate for November 2006 (1\$+Rs.60.728219)

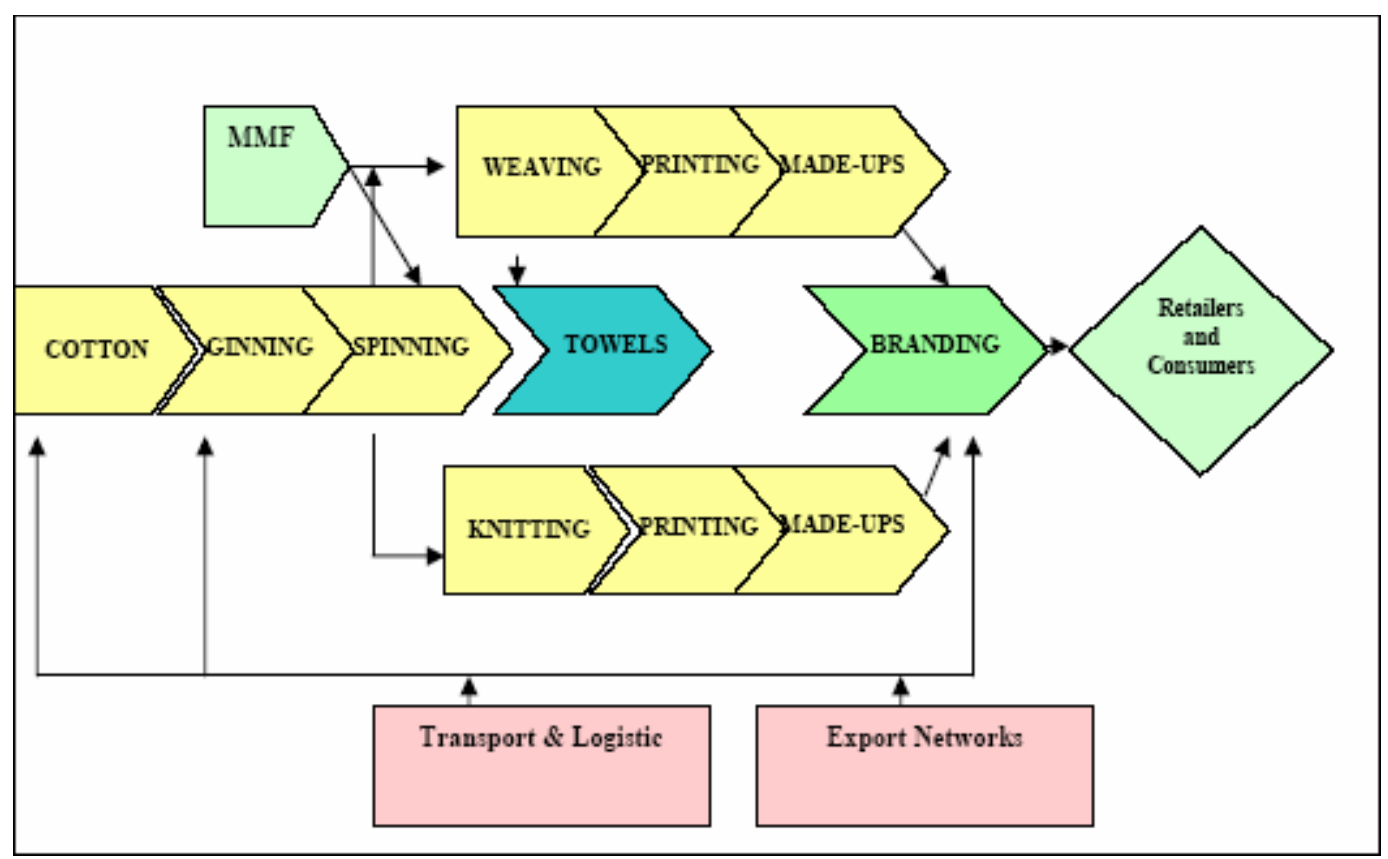

Figure 4.4. Textile Value Chain

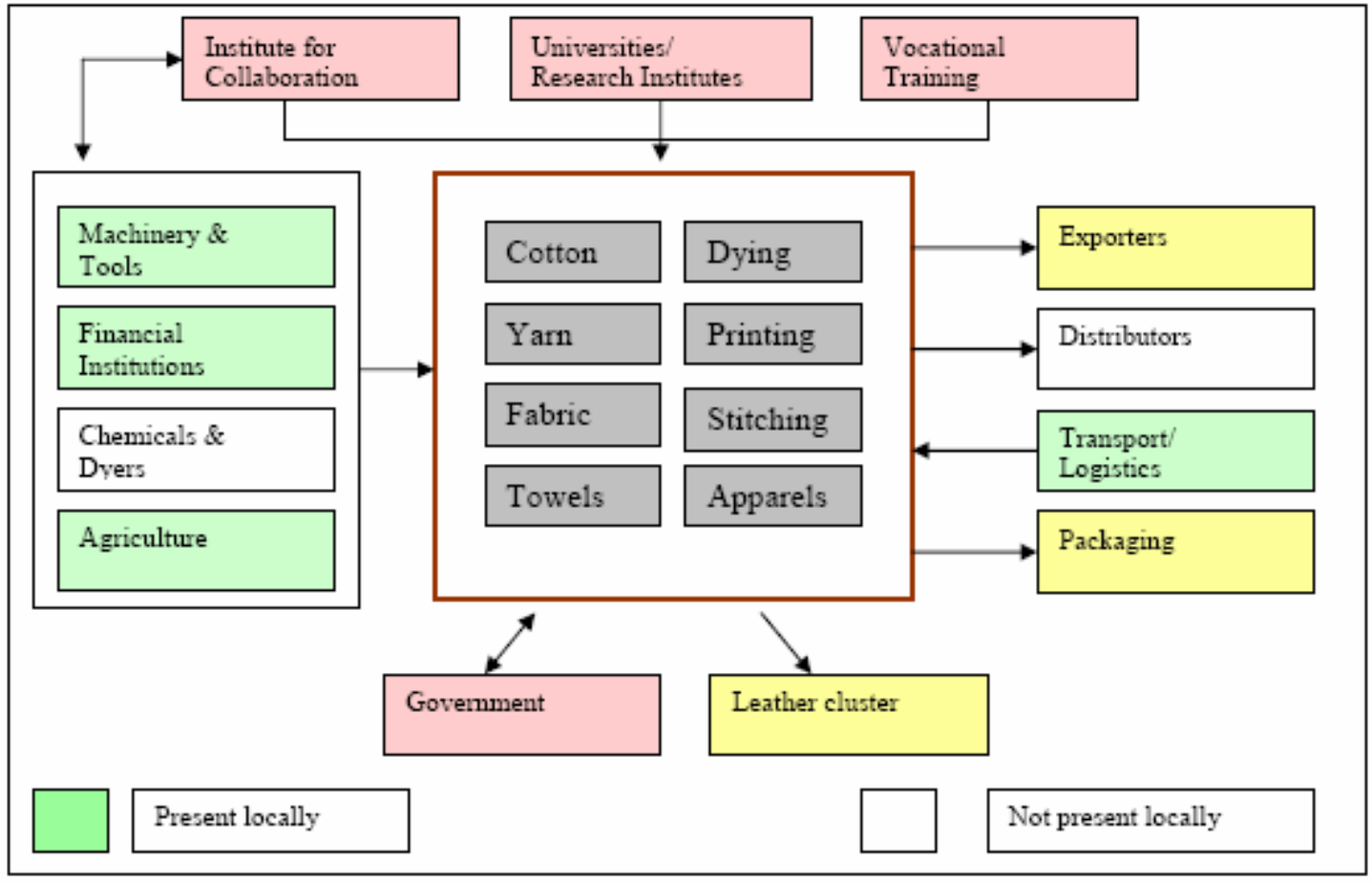

\section{Strengths}

Pakistan is the fourth largest producer of cotton (9\% world share) and is endowed with fertile lands and extensive irrigation network (USDA 2007; UNU 2007). The Global financial crisis has negative impact in the 
textile industry specially the cotton made garments. Major strengths are quality, innovation, timely supply, designing.

\section{CONCLUSIONS}

Pakistan is the fourth largest producer of cotton and cotton made garments in the world. Pakistan is exporting cotton made garments to the western as well as Asian countries. The export of textile related products has decreased by 20 percent due to decrease in textile demand. It was further revealed that textile industry facing problems of like electricity and issues like high taxes. Keywords: Textile, Clusters, Empirical analysis, Pakistan. Government should focus on the issues related to textile industry to develop this textile sector in Pakistan.

\section{AUTHOR INFORMATION}

Faiz Muhammad Shaikh is an assistant professor in the Department of Agricultural Economics at Shaheed Zulfiqar Ali Bhutto Agricultural College Dokri, which is a constituent college of Sindh Agriculture University Tando Jam. He has an MBA from one of the leading business School IBA Karachi. He has published 64 research articles in various international journals and in 100 international conference proceedings. His research interests are FDI, poverty, Islamic banking, credit, and international trade.

Nazir Ahemed Gopang is an assistant professor at the University of Sindh Jamshoro. He has published 10 research papers. His areas of interest are FDI and Poverty.

\section{REFERENCES}

1. Bari, K. Malik (2003). The Competitive Advantage of Pakistan - Empirical Analysis of the Textile/Apparel Industry, PhD Thesis, University of Strathclyde, Glasgow, U.K.

2. Cotton Counts 2007. [Online] Available: $(20 / 11 / 2009)$.

3. Economist Intelligence Unit's. [Online] Available: www.eiu.com. (25/11/2009).

4. Government of Pakistan, (various years), Economic Survey of Pakistan, Ministry of Finance, Islamabad.

5. Government of Pakistan, (various years), Pakistan Statistical Year Book, Federal Bureau of Statistics (FBS), Statistics Division, Islamabad.

6. Government of Pakistan. (2000). Textile Vision 2005. Islamabad, Pakistan.

7. Government of Pakistan. (2002). Ministry of Commerce, Text of the Trade Policy of Pakistan, Islamabad, Pakistan.

8. Khan, S. R. (1999). Fifty Years of Pakistan Economy: Traditional Topic and Contemporary Concerns. Oxford University Press, Karachi, Pakistan.

9. Sheikh, H. R. (2005). Growth and BMR Requirements of the Textile Industry-Problems and Prospects, Textile Institute of Pakistan.

10. Small and Medium Enterprise Development Agency (SMEDA), 2000. [Online] Available: www.smeda.org. (28/12/2009).

11. Trade Development Authority of Pakistan. [Online] Available: www.epb.gov.pk. (25/12/2009).

12. United States Department of Agriculture (USDA). (2007). [Online] Available: www.usda.gov. (30/12/2009).

13. World Development Indicators various issues

14. [Online] Available: www.pakistan.gov.pk/ministries/index.jsp?MinID. (10/10/2009).

15. [Online] Available: www.epb.gov.pk. (20/11/2009).

16. [Online] Available: www.worldbank.org. (20/12/2009). 


\section{NOTES}

